\title{
Hepatitis E: Still Waters Run Deep
}

\author{
Moritz von Wulffen ${ }^{1}$, Dirk Westhölter ${ }^{1}$, Marc Lütgehetmann ${ }^{2}$ and Sven Pischke*1 \\ ${ }^{1}$ Department of Medicine I, University Medical Center Hamburg-Eppendorf, Hamburg, Germany; ${ }^{2}$ Institute for Medical \\ Microbiology, University Medical Center Hamburg-Eppendorf, Hamburg, Germany
}

\begin{abstract}
Hepatitis $E$ is an infectious inflammatory disease of the liver caused by the hepatitis E virus (HEV), a single-stranded RNA virus. Today, it is estimated that there are more than 20 million HEV infections every year, leading to 3.3 million symptomatic cases and more than 56,000 deaths. For a long time it was believed that HEV was a travel-associated disease, endemic in developing countries with poor hygienic standards and unsafe water supply. However, over the past years, publications have demonstrated that autochthonous HEV infections in industrialized countries are far more common than previously thought. Awareness for HEV amongst health care practitioners in industrialized countries is still limited. This relatively rare disease is of great importance, especially in immunocompromised patients where it can cause chronic liver disease. This article comprehensively reviews current literature to give an overview on clinically important topics. It will focus on epidemiological aspects, acute and chronic HEV infection as well as extra-hepatic manifestations, diagnostic approach and treatment options. Furthermore, the article is concluded with a brief outlook on perspectives and urgent problems to be addressed in the future.
\end{abstract}

Citation of this article: von Wulffen $M$, Westhölter $D$, Lütgehetmann M, Pischke S. Hepatitis E: still waters run deep. J Clin Transl Hepatol 2018;6(1):40-47. doi: 10.14218/JCTH.2017.00030.

\section{Introduction}

Hepatitis $E$ is an infectious disease causing acute and - under specific conditions - chronic inflammation of the liver. The disease is caused by the hepatitis E virus (HEV), which is a small, single-stranded RNA virus. It is the sole member of the genus Hepevirus, in the family of Hepeviridae. ${ }^{1}$ The existence of the virus was first hypothesized following an outbreak in the Kashmir valley of India in 1978, causing 52,000 icteric patients and 1,700 deaths. ${ }^{2}$ However, it took another decade to sequence the full genome of the virus.

The taxonomy of HEV genotypes (GTs) and strains is undergoing a permanent evolution. ${ }^{3}$ Traditionally, it was

Keywords: Hepatitis E; Hepatitis E virus (HEV); Ribavirin; Transplantation; Extrahepatic.

Abbreviations: ALT, alanine aminotransferase; FDA, Food and Drug Administration; GT, genotype; HEV, hepatitis E virus; HIV, human immunodeficiency virus; NAT, nucleic acid testing.

Received: 30 April 2017; Accepted: 19 August 2017

*Correspondence to: Sven Pischke, Department of Medicine I, University Medical Center Hamburg-Eppendorf, Martinistrasse 52, Hamburg 20246, Germany. Tel: +49-40-7410-53910, Fax: +49-40-7410-58531, E-mail: s.pischke@uke.de grouped into four different GTs (HEV GT 1-4). Recently, it was demonstrated that there are actually eight different GTs, based on the reference sequences. ${ }^{1,3}$ However, clinical and epidemiological characteristics of the "new" GTs need further clarification. GT 1-4 are the classical humanopathogenic GTs and show a specific geographical distribution. GT 1 and 2 are endemic in a number of tropical countries with frequent water contaminations and are transmitted via the fecal-oral route. ${ }^{4}$ In European industrialized countries, GT 3 is most common while GT 4 is common in industrialized Asian nations. Recently, HEV GT 4 has been described to be present in Europe in single cases and is not limited to Asia. ${ }^{5}$ GT 3 and 4 are known zoonoses and transmitted via consumption of undercooked or raw meat. Domestic swine, wild boar and deer are classic examples as sources of HEV infection (Table 1). In addition, camels, rabbits, chicken, rats, bats and other animals have been identified as reservoirs of the virus. ${ }^{6-9}$ Furthermore, it can also be transmitted by viremic blood products ${ }^{10}$ and by such vegetables and fruits as spinach, rocket, mixed salads or strawberries. ${ }^{11,12}$

Today it is estimated that there are more than 20 million tropical HEV infections every year, leading to 3.3 million symptomatic cases and more than 56,000 deaths, while symptomatic hepatitis $\mathrm{E}$ in industrialized countries is a rare disease. 4,13 Most cases of HEV infection are asymptomatic. Following an incubation period of 2-10 weeks, usually unspecific symptoms (e.g., mild fever, reduced appetite, abdominal pain, joint pain, rash, dark urine, pale stools, jaundice, enlarged and tender liver) last for 1-6 weeks. ${ }^{9}$ These symptoms are indistinguishable from those of other liver diseases. The related acute liver failure most often occurs in pregnant women, who are also at risk of fetal loss. ${ }^{14}$

Usually, HEV is an acute self-limiting disease. ${ }^{4}$ However, in immunosuppressed individuals, such as solid organ recipients, GT 3 and 4 can cause chronic hepatitis leading to cirrhosis and its complications. ${ }^{4}$ This has not been reported for GT 1 or 2 . There are also some extra-hepatic manifestations associated with HEV, including Guillain-Barre syndrome and cryoglubulinemia, amongst others. ${ }^{15}$

There are different treatment options for chronic hepatitis $E$, including reduction of immunosuppression, administration of pegylated-interferon $\alpha$ or use of ribavirin. However, no drug has yet been approved for the treatment of HEV infections. Randomized studies are needed to validate the value of ribavirin for the treatment of acute or chronic HEV infections.

\section{History of hepatitis E}

In 1978 , the first described outbreak of hepatitis $E$ took place in the Kashmir valley, a very rural and poor part of India. ${ }^{2}$ While many believed that this was a hepatitis A or B epidemic, 
von Wulffen M. et al: Hepatitis E: still waters run deep

Table 1. HEV genotypes and sources of infection

\begin{tabular}{|c|c|c|c|}
\hline HEV genotype & Area & Sources of infection & Comment \\
\hline GT 1 & $\begin{array}{l}\text { Tropical developing } \\
\text { countries of Asia and Africa }\end{array}$ & $\begin{array}{l}\text { Contaminated } \\
\text { drinking water }\end{array}$ & $\begin{array}{l}\text { No zoonotic relevance } \\
\text { No chronic infections described }\end{array}$ \\
\hline GT 2 & $\begin{array}{l}\text { Tropical countries of Africa } \\
\text { or Mexico/ Central America }\end{array}$ & $\begin{array}{l}\text { Contaminated } \\
\text { drinking water }\end{array}$ & $\begin{array}{l}\text { No zoonotic relevance } \\
\text { No chronic infections described }\end{array}$ \\
\hline GT 3 & $\begin{array}{l}\text { Industrialized nations, } \\
\text { worldwide distribution, } \\
\text { autochthonous in Europe, } \\
\text { North and South America, } \\
\text { Australia and large parts of } \\
\text { Asia }\end{array}$ & $\begin{aligned} & \text { Foodborne zoonosis } \\
& \rightarrow \text { Swine } \\
& \rightarrow \text { Deer } \\
& \rightarrow \text { Cats } \\
& \rightarrow \text { Rats } \rightarrow \text { Rabbits } \\
& \rightarrow \text { Mongooses } \rightarrow \text { Cows } \\
& \rightarrow \text { Cow's milk } \\
& \rightarrow \text { Sheep } \\
& \rightarrow \text { Strawberries } \\
& \rightarrow \text { Vegetables } \\
& \rightarrow \text { Blood products }\end{aligned}$ & $x^{2}$ \\
\hline GT 4 & $\begin{array}{l}\text { Mainly in Asia, recently } \\
\text { single cases in Europe }\end{array}$ & $\begin{array}{l}\text { Foodborne zoonosis } \\
\rightarrow \text { Swine }\end{array}$ & $\begin{array}{l}\text { Chronic HEV infections described } \\
\text { in single immunosuppressed } \\
\text { patients }\end{array}$ \\
\hline GT 5 & Japan & Wild boar & Relevance for humans still unclear \\
\hline GT 6 & Japan & Wild boar & Relevance for humans still unclear \\
\hline GT 7 & Middle East & $\begin{array}{l}\text { Dromedary camels } \\
\text { (one-humped camels) }\end{array}$ & $\begin{array}{l}\text { Chronic infection in a liver } \\
\text { transplant recipient who regularly } \\
\text { consumed camel meat and milk }\end{array}$ \\
\hline GT 8 & Middle East & $\begin{array}{l}\text { Bactrian camels (two- } \\
\text { humped camels) }\end{array}$ & Relevance for humans still unclear \\
\hline
\end{tabular}

the epidemiological and clinical features did not quite fit hepatitis A or B; those features being predominantly young adults affected and pregnant women having shown very high mortality rates. The course of disease was self-limited. Ultimately, sera were lacking serological markers of hepatitis A and B. It was then hypothesized that there must be another virus distinct from hepatitis $A$ and $B$ as well as from the post-transfusion non-A, non-B hepatitis (hepatitis $C$ ), due to the mode of infection. Further studies revealed that this still unknown virus was endemic in India and the major cause of acute sporadic viral hepatitis. ${ }^{2}$

In 1981, another outbreak of hepatitis E amongst Russian military personal stationed in Afghanistan occurred. This epidemic resembled features similar to the outbreak in Kashmir. In a self-experimentation, Balayan ingested pooled stools of nine infected soldiers. ${ }^{16}$ He subsequently developed jaundice and elevated liver tests. Later, his team discovered virus-like particles, which were visualized by immune electron microscopy. These particles reacted in the immune electron microscopy test with sera from individuals who had experienced two non-B hepatitis episodes but did not react with sera from routine anti-HAV IgM-positive hepatitis patients. Later, primates were experimentally infected with virus-containing stool extract which resulted in histopathologically confirmed hepatitis and abnormal liver tests.

It took another 10 years before the full genome of the virus was sequenced in 1991 and diagnostic assays were developed. ${ }^{2}$ In the past few years, the perception of hepatitis $E$ in industrialized countries has shifted from a mere travel-associated disease to a disease with autochthonous infections. ${ }^{4}$ In 2010, a detailed phylogenetic analysis of the HEV GTs 1, 3 and 4 studied the descent of modern HEV GTs and revealed that the most recent common ancestor existed between the $7^{\text {th }}$ and $15^{\text {th }}$ century. ${ }^{17}$ Furthermore, a substantial temporal variation in the rate of transmission among HEV GTs in different geographic regions late in the 20th century has been suggested. ${ }^{17}$ 


\section{Enveloped or non-enveloped virus?}

HEV is an enterically transmitted hepatotropic virus. For decades this virus has been assumed to be non-enveloped only. ${ }^{18}$ In contrast, recent studies have demonstrated that HEV is completely cloaked in host membranes and resistant to neutralizing antibodies while circulating in the patient's blood. In summary, there are two variants, one enveloped and one nonenveloped. ${ }^{18}$ The clinical and pathophysiological features of these variants still need to be studied in more detail, especially to identify the differences regarding organ tropism and infectivity. Furthermore, the receptor which enables cellular entry of HEV still needs to be determined.

\section{Epidemiology}

It is estimated that there are more than 20 million HEV infections every year in the tropics, leading to 3.3 million symptomatic cases and more than 56,000 deaths. ${ }^{13}$ However, robust data on seroprevalence rates of anti-HEV IgG in tropical countries is largely lacking. In industrialized countries, far less symptomatic cases of HEV infection are reported.

Recently, a large meta-analysis revealed that the seroprevalence rates primarily depend on the seroassay used, followed by the geographical region and the cohort of individuals studied. ${ }^{19}$ Seroprevalence is higher in individuals exposed to swine and/or wild animals, and increases with age. ${ }^{19}$ Various European countries, such as France or the Netherlands, have anti-HEV rates of more than $30 \% .{ }^{19}$

Testing for HEV antibodies is, to date, a field of controversy. It is still under debate which assay to use, and the Food and Drug Administration (FDA) has not yet approved a single assay in the United States to test for HEV. Due to limited sensitivity of several assays, older epidemiological studies on seroprevalence of anti-HEV IgG in Europe largely underestimated the burden of the disease. ${ }^{19}$ On the contrary, various studies have shown a decline of the seroprevalence in several industrialized countries over time. ${ }^{19}$ However, while seroprevalence rates have seemed to decrease, the rate of reported $\mathrm{HEV}$ infections and symptomatic cases is increasing in Europe. ${ }^{20}$ This apparent contradiction can be explained by a raised awareness for HEV amongst health care practitioners.

There is a specific geographic distribution of the GTs 1-4 (Table 1 ). While GT 1 is responsible for most cases of endemic and epidemic HEV in Asia, GT 2 is the main source of infection in Africa and Central America. ${ }^{9}$ GTs 1 and 2 are obligate human pathogens and are transmitted via the fecal-oral route. ${ }^{9}$

Areas with poor hygiene standards, high population density and unsafe water supply are most often affected. ${ }^{9}$ Refugee camps are also prone to outbreaks. ${ }^{21,22}$ Sporadic cases in the tropics as well as large outbreaks typically affect young adults (15-30 years-old). It is unclear why children are less often infected, since infections via the fecal-oral route are often infections of the first decade of life, such as is seen for hepatitis A. Incidence of symptomatic disease and mortality rates are much higher in pregnant women as compared to other groups of patients. ${ }^{14}$

In contrast to GTs 1 and 2, GTs 3 and 4 are found in humans and various animals (e.g., domestic swine, wild boar, deer, camels, chicken, rabbits, rats, bats and others) in Europe, the United States and Asia. ${ }^{9}$ Furthermore, HEV-specific antibodies could be found in sheep and cows. ${ }^{23}$ Especially for the European HEV GT 3, several different sources of infection have been described (Table 1). The main source of infection in industrialized countries is the consumption of raw or undercooked meat of domestic pig. ${ }^{9}$ The role of contact with other animals as source of infection is less clear and needs further investigation. There are also reports on direct transmission between humans, infection via transplanted organs and also consumption of salads and strawberries. ${ }^{11,12,24}$ Furthermore, there is a report from China suggesting milk products as potential source of HEV GT $4 .{ }^{25}$ However, the virus becomes inactivated upon heating over $70^{\circ} \mathrm{C}$.

Another source of infection with GTs 3 and 4 are blood products, including blood plasma. In Europe, 1:1.000 to $1: 10.000$ blood donors are HEV viremic (Table 2). Recent unpublished data from our own group suggested an even higher HEV RNA prevalence among blood donors in some European regions. One of the largest studies was conducted in Southeast England, in which 225,000 blood donations were tested retrospectively. ${ }^{10}$ Seventy-nine of these donations had detectable HEV RNA (1:2850). Follow-up of 43 recipients revealed $18(43 \%)$ developed signs of HEV infection. Ten recipients developed prolonged viremia. Three immunocompromised recipients needed ribavirin treatment to clear the infection, and only one patient developed apparent posttransfusion hepatitis. Two cases of transfusion-transmitted HEV infections by erythrocyte and platelet concentrates from one asymptomatic donor were reported from Germany; ${ }^{26}$ both recipients were immunocompromised, presented with elevated alanine aminotransferase (ALT) and developed a chronic course of the infection. Other cases of transfusionassociated hepatitis E were reported from Australia, France, the United Kingdom, Spain and Japan (Table 3). ${ }^{27-37}$

The aforementioned studies demonstrated that HEV viremic donors were mostly asymptomatic and showed no elevated ALT at time of donation. Thus, blood donor interviews are not effective to identify viremic donors. Also, studies on feasible procedures to safely inactivate the HEV are missing. Recently, the general HEV RNA screening of blood donations is discussed controversially. On the one hand, rapid progression to liver cirrhosis in chronically HEV-infected immunosuppressed patients has been documented. On the other hand, robust data are lacking on whether HEV RNA screening of blood products can effectively reduce HEV infections in immunocompromised patients, as dietary exposure still affects them.

Table 2. Extra-hepatic manifestations (modified from Pischke et al. J Hepatol $2017^{15}$ )

\begin{tabular}{|c|c|}
\hline $\begin{array}{l}\text { Extra-hepatic } \\
\text { manifestation }\end{array}$ & $\begin{array}{l}\text { Likelihood of causal } \\
\text { relationship }\end{array}$ \\
\hline Neuralgic amyotrophy & Likely (associated with GT 3) \\
\hline Guillain-Barre syndrome & Likely (associated with GT 3) \\
\hline Pancreatitis & Likely (associated with GT 1) \\
\hline Glomerulonephritis & Likely (associated with GT 3) \\
\hline Cryoglobulinemia & Possible (associated with GT 3) \\
\hline $\begin{array}{l}\text { Hematological } \\
\text { diseases }\end{array}$ & $\begin{array}{l}\text { Possible (associated with } \\
\text { GTs } 1 \text { and } 3 \text { ) }\end{array}$ \\
\hline Meningitis & Possible (associated with GT 3) \\
\hline $\begin{array}{l}\text { Autoimmune } \\
\text { hepatitis }\end{array}$ & $\begin{array}{l}\text { Still unclear (associated } \\
\text { with GT 3) }\end{array}$ \\
\hline Thyroiditis & Doubtful (associated with GT 3) \\
\hline Myocarditis & Doubtful (associated with GT 3) \\
\hline
\end{tabular}


von Wulffen M. et al: Hepatitis E: still waters run deep

Table 3. HEV viremia among blood donors

\begin{tabular}{|c|c|c|c|c|}
\hline Country & Method & Samples & Results & Author, Journal Year ${ }^{\text {Ref }}$ \\
\hline Canada & Pools of $48 / 100$ & 13.993 & 0 in 13.993 & Fearon et al., Transfusion $2017^{78}$ \\
\hline France & Pools of 96 & 53.234 & $1: 2218$ & Gallian et al., Emerg Infect Dis $2014^{79}$ \\
\hline \multirow[t]{2}{*}{ Germany } & Pools of 48 & 16.000 & $1: 1250$ & Vollmer et al., J Clin Microbiol $2012^{80}$ \\
\hline & Pools of 96 & 18.100 & $1: 4525$ & Baylis et al., Vox Sang $2012^{81}$ \\
\hline Spain & Pools of & 9.998 & $1: 3333$ & Sauleda et al., Transfusion $2015^{82}$ \\
\hline The Netherlands & Pools of $96 / 192$ & 59.474 & $1: 1440$ & Hogema et al., Transfusion $2016^{83}$ \\
\hline United States & Singly & 18.829 & $1: 9500$ & Stramer et al., ISBT Sci Ser $2014^{84}$ \\
\hline United Kingdom & Pools of 24 & 225.000 & $1: 2850$ & Hewitt et al., Lancet $2014^{10}$ \\
\hline
\end{tabular}

A cost-effectiveness study from the Netherlands using a simulation model concluded that HEV RNA screening of blood products is not excessively expensive compared to other screening tests. ${ }^{38}$ In that study, the authors estimated only 1 in $700 \mathrm{HEV}$ infections to be transfusion-associated in the Netherlands. ${ }^{38}$

All in all, uncertainties about the epidemiology of HEV remain. So far, only the United Kingdom has implemented an HEV screening of blood products intended for patients at risk of chronic HEV infection. The European Pharmacopoeia introduced a general HEV RNA screening of plasma pools for the production of solvent/detergent plasma. In healthy subjects, less than $5 \%$ of HEV infections become symptomatic. ${ }^{9}$ The reasons for this low manifestation rate are unclear and it can only be speculated that factors like viral load exposure, pathogenicity of HEV strain, genetic and immunological features play a role. ${ }^{9}$

\section{Acute hepatitis E}

In immunocompetent individuals HEV infection is usually asymptomatic, especially during childhood. ${ }^{9}$ Most cases of symptomatic, acute hepatitis $\mathrm{E}$ worldwide occur in the tropics and are caused by GTs 1 and $2 .^{9}$ Some differences between GTs and course of acute HEV infection have been observed. HEV GT 1 or 2 infection is usually a disease of young adults, while GT 3 infection in higher income countries usually affect older males. ${ }^{39,40}$ Furthermore, HEV GT 1 and 2 infections seem to be associated with a more severe disease and a higher manifestation rate. ${ }^{41,42}$ While manifestation rates in industrialized countries are relatively clear (1-2\%), there is a lack of robust data on seroprevalence and manifestation rates in developing countries. ${ }^{9}$

Typical symptoms of HEV include unspecific symptoms, such as mild fever, reduced appetite, abdominal pain, joint pain and rash. Some patients may develop dark urine, pale stools, jaundice, itching and an enlarged, tender liver. ${ }^{9}$ This is usually accompanied by abnormal liver tests. Symptoms occur after an incubation period of 2-6 weeks. ${ }^{9}$ Patients very rarely develop acute liver failure. In the tropics, most cases of severe liver disease and acute liver failure occur in pregnant women. ${ }^{14,43}$ It is speculated that this is due to hormonal and immunological changes during pregnancy. ${ }^{14,44} \mathrm{An}$ association between reduced expression of the progesterone receptor and fatal outcome of hepatitis $E$ in pregnant women has been reported. ${ }^{45} \mathrm{~A}$ German study comparing imported and autochthonous HEV infections $(n=27)$ demonstrated that imported HEV infections are associated with higher transaminases, international normalized ratio and bilirubin levels compared to autochthonous cases. ${ }^{42}$ That study demonstrated an association between the HEV GTs and severity of the hepatitis disease.

Another study investigated if there is an association between variability and pathogenicity of various HEV GT 3 subtypes. ${ }^{46}$ However, despite that study containing more than 600 patients from four countries, no association between severity of hepatitis E and HEV GT 3 subtypes was found. ${ }^{46}$ Thus, the clinical relevance of GT 3 subtypes still needs to be determined, while the relevance of the main GTs has been suggested. The most relevant group of patients at risk for a more severe course of HEV GT 3 infection are patients with underlying chronic liver disease, such as alcohol abuse, chronic viral hepatitis, non-alcoholic steatohepatitis, autoimmune liver disease or hereditary liver diseases. ${ }^{9}$ Acute-onchronic liver failure due to acute HEV infection is a potentially life-threatening complication.

In industrialized countries, there are some case reports on prolonged viremia in immunocompetent individuals. ${ }^{47}$ However, prolonged viremia in "healthy" individuals should always raise suspicion for an undiagnosed disturbance of the immune system. ${ }^{48}$ To date, no case of HEV-associated cirrhosis or complications of cirrhosis in immunocompetent individuals has been published and no case of development of hepatocellular carcinoma has been observed in patients with chronic hepatitis E and cirrhosis.

\section{Chronic hepatitis E}

In 2008, Kamar et al. ${ }^{49}$ and Gerolami et al. ${ }^{50}$ described chronic hepatitis $\mathrm{E}$ in liver and kidney transplant recipients. Systematic studies revealed that the prevalence of HEV infection in cohorts of liver or kidney transplant recipients was approximately $1 \%$ in a Dutch and a German cohort. ${ }^{51,52}$ In addition to liver or kidney transplant recipients, chronic hepatitis $E$ has also been observed in heart or lung transplant recipients as well as patients infected with the human immunodeficiency virus (HIV) and stem cell transplant recipients. ${ }^{53-55}$ Interestingly, heart transplant recipients have a much higher anti-HEV seroprevalence than liver or kidney transplant recipients, healthy controls or cardiac patients without transplantation. ${ }^{54}$ This increased seroprevalence has been confirmed by two independent serological assays. ${ }^{56}$ Perhaps this phenomenon is caused by the high rate of blood products that heart transplant recipients receive.

Chronic hepatitis E can lead to fibrosis, cirrhosis and chronic liver failure. However, reduction of immunosuppression or 
treatment with ribavirin are possible therapeutic strategies. ${ }^{57}$ Even in patients who failed to achieve clearance of the virus (i.e. sustained virological response), it could be demonstrated that regression of liver fibrosis might occur. ${ }^{58}$ Furthermore, it has been demonstrated that established HEV infection in immunosuppressed individuals, such as HIV-patients, might persist despite recovery of the immune system. ${ }^{59}$

It is still under debate if HEV GT 1 or 2 can also induce chronic hepatitis E. However, a study from India did not observe any case of chronic hepatitis $E$ in a cohort of 205 kidney transplant recipients. ${ }^{60}$ Despite $7 \%(n=14)$ of studied patients having had detectable anti-HEV IgM - indicating recent contact with $\mathrm{HEV}$ - no patient developed chronic infection (0/14). In contrast, $47 \%(16 / 34)$ of French kidney transplant recipients with HEV infection after transplantation developed chronic hepatitis $E$ in a large study. ${ }^{61}$ Thus, Indian kidney transplant recipients with HEV GT 1 infections either do not develop chronic HEV infections or do so far more rarely than French kidney transplant recipients $(p<0.001$, chi-square test).

However, in another Asian country, in Japan, GTs 3 and 4 are prevalent. In a large Japanese multicentric cohort study of liver transplant recipients only $0.12 \%$ of patients (2/1651) suffered from chronic HEV infection. ${ }^{62}$ This low rate of HEV infections in transplant recipients was significantly lower than in seven European cohorts of transplant recipients, in which a prevalence of chronic HEV infection was found at rates of $0.7 \%$ to $3.2 \%$ (median: $1.4 \%$ ). ${ }^{63}$ In summary, neither in GT 1 nor in GT 3 endemic regions in Asia does chronic HEV have the same importance as in Europe. Data about chronic hepatitis $\mathrm{E}$ in the United States are scarce due to no FDAapproved test being available. ${ }^{64,65}$

\section{Extra-hepatic manifestations}

Several extra-hepatic symptoms and diseases have been associated with acute or previous HEV infection (Table 2). ${ }^{15}$ Some of these diseases might be caused by direct effects of the virus to tissue of organs other than the liver, and some might be caused by an overwhelming immune response stimulated by HEV. Still others of these phenomena might not be associated with HEV but might only have occurred accidentally and occasionally in the context of hepatitis E. A proven pathophysiological link has still not been established for any of these assumed "extra-hepatic manifestations of HEV infection".

While pancreatitis has frequently been observed in the context of tropical HEV infections, glomerulonephritis or such neurological symptoms as neurologic amyotrophy or GuillainBarre syndrome have frequently been associated with HEV GT 3 infections in industrialized countries. ${ }^{15}$ However, it still needs to be determined if a tropism of the various GTs is causative for this phenomenon.

\section{Diagnosis of HEV}

The laboratory diagnosis of HEV infection is based on the detection of antibodies against HEV (IgM and IgG), detection of HEV antigen or detection of HEV RNA in plasma, serum or stool through quantitative PCR. Anti-IgM-antibodies are markers of acute HEV infection. They are detectable within 2-4 weeks after infection and persist for 3-5 months afterwards. Also, anti-HEV IgA has been shown to be a marker of acute infection, but is not established in routine diagnostics. ${ }^{66}$ Anti-IgG antibodies last for many years, represent a previous exposure to HEV and are detectable in $95 \%$ of patients at initial clinical presentation. ${ }^{67}$

Viral nucleic acid testing (NAT) in plasma, serum and stool is a highly sensitive method to detect HEV infection and might be essential in diagnosing HEV infection in the immunocompromised, as some patients remain antibody-negative. Hence, NAT is the preferred diagnostic method. Non-standardized assays used in laboratories worldwide have differences in sensitivity and specificity for HEV RNA and antibody testing. In 2013, international standards for HEV PCR techniques were introduced in a World Health Organization initiative to improve comparability of HEV prevalence data. ${ }^{68}$

\section{Treatment}

There is little literature on the treatment of hepatitis $E$, especially for acute hepatitis $E$, and so far no drug has been approved for the treatment of acute or chronic hepatitis $E$. However, it should be kept in mind that most infections with HEV are self-limited and therefore do not need to be treated.

In the setting of acute hepatitis $E$, the knowledge on treatment options is very limited. However, there are reports that ribavirin is a possible treatment option to prevent fatal cases of acute and acute-on-chronic liver failures. ${ }^{69-72}$ To date, no case-controlled studies have been conducted on the efficacy of ribavirin in acute hepatitis $E$. Thus, whether patients with acute hepatitis $E$ should be treated in centers with experience and whether ribavirin therapy should be initiated needs to be decided on a case-by-case basis.

Treatment options for chronic hepatitis $E$ include the use of ribavirin administration of pegylated-interferon and reduction of immunosuppression. The first step in this setting should be the evaluation of the possibility to reduce immunosuppression. ${ }^{57}$ Approximately $50 \%$ of HEV infections in transplant recipients lead to chronic hepatitis E. ${ }^{54,61}$ Thus, treating each immunosuppressed patient with diagnosed hepatitis $E$ will result in unnecessary treatment of half of the patients. Ribavirin use for treatment of hepatitis $E$ presents an offlabel medication with possible side effects, mainly anemia. To avoid unnecessary ribavirin courses in patients who will clear the infection spontaneously, only patients chronically infected with HEV, patients who develop liver failure caused by HEV or patients with assumed HEV-associated severe extra-hepatic manifestations should be treated with ribavirin (Fig. 1). This leads to elimination of the virus in the vast majority of cases.

\section{Vaccination}

Initially, a promising vaccine was evaluated in 2006 within a large trial containing 2000 Nepalese soldiers and showed effective prevention of hepatitis $E .{ }^{73}$ However, further development and distribution of this vaccine has been stopped. A further vaccine has been studied within a large trial ( $n>11.000$ individuals) and has shown safety and efficacy to prevent hepatitis E. ${ }^{74}$ This vaccine (Hecolin) has been approved for the use in China, where it has been available since 2012.

There are still no data on the use of the Hecolin vaccine in transplant recipients and/or patients with HEV GT 3 infections. A topic of special relevance is the use of this vaccine in pregnant women, as $10 \%$ of maternal deaths in rural Bangladesh are caused by HEV, and this indicates that more than 10,000 cases of maternal deaths in Southern Asia could be 


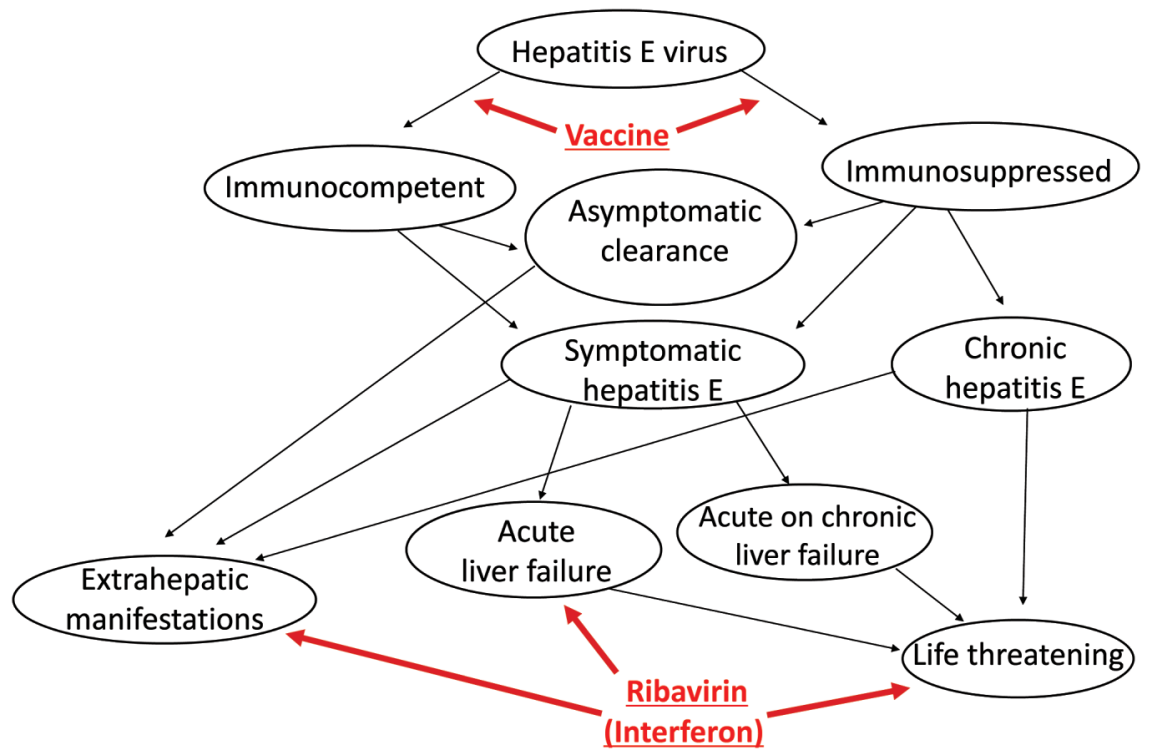

Fig. 1. Possible courses of HEV infection and optional interventions.

prevented by this vaccine. ${ }^{75}$ This topic has been under intensive debate within the World Health Organization. ${ }^{76}$ Within the successful phase 3 study of the Hecolin vaccine there were inadvertently 37 pregnant women in the vaccine group and 31 in the placebo group. ${ }^{77}$ However, there were no severe adverse events reported in these women, indicating safety of the vaccine during pregnancy. While 19 women in the vaccine group and 14 in the placebo group underwent elective abortion there were 18 and 17 live births in the vaccine and the placebo group, respectively. However, these data represented a small subgroup and further larger studies are necessary to determine the value of the vaccine in pregnant women.

\section{Perspectives}

There is an urgent need for treatment options for acute hepatitis $\mathrm{E}$ in pregnant women in the tropics. Due to potential feto-toxicity of ribavirin, it is contra-indicated in these patients. However, pregnant women have the highest mortality rates of all hepatitis $\mathrm{E}$ patients. This raises the question if ribavirin could be beneficial in this setting. However, to date there is no study to evaluate this. Furthermore, use of the vaccine for pregnant women needs to be clarified.

Despite several diseases having been suspected as the cause, the trigger of or as being promoted by HEV infection, the pathophysiological link between any of these diseases and HEV has still not been established and needs further investigation.

Optimal treatment strategies for patients with HEV-induced acute liver failure or for immunosuppressed patients with chronic hepatitis E need to be established. There are several reports about the use of ribavirin for the treatment of HEV infections. However, the optimal dosage and treatment duration still needs to be determined. Furthermore, the role of HEV mutations and their prognostic value for prediction of non-response should be clarified.

The relevance of blood-borne HEV transmission and the risk for various subgroups of recipients of blood products requires further investigation. Furthermore, the responsible governments worldwide need to discuss the question of whether blood products should be tested for HEV.

\section{Conflict of interest}

The authors have no conflict of interests related to this publication.

\section{Author contributions}

Conception of study objectives and/or design, interpretation of findings, drafting the article (MW, ML, SP), interpretation of findings, revising the article for important intellectual content $(D W)$, revising the article for important intellectual content $(\mathrm{ML}, \mathrm{SP})$.

\section{References}

[1] Smith DB, Simmonds P; International Committee on Taxonomy of Viruses Hepeviridae Study Group, Jameel S, Emerson SU, Harrison TJ, et al. Consensus proposals for classification of the family Hepeviridae. J Gen Virol 2014; 95:2223-2232. doi: 10.1099/vir.0.068429-0.

[2] Khuroo MS. Discovery of hepatitis E: the epidemic non-A, non-B hepatitis 30 years down the memory lane. Virus Res $2011 ; 161: 3-14$. doi: $10.1016 / \mathrm{j}$. virusres.2011.02.007.

[3] Sridhar S, Teng JLL, Chiu TH, Lau SKP, Woo PCY. Hepatitis E virus genotypes and evolution: emergence of camel hepatitis E variants. Int J Mol Sci 2017; 18:869. doi: $10.3390 /$ ijms 18040869.

[4] Pischke S, Wedemeyer H. Hepatitis E virus infection: multiple faces of an underestimated problem. J Hepatol 2013;58:1045-1046. doi: 10.1016/j. jhep.2012.12.013.

[5] Jeblaoui A, Haim-Boukobza S, Marchadier E, Mokhtari C, Roque-Afonso AM. Genotype 4 hepatitis e virus in france: an autochthonous infection with a more severe presentation. Clin Infect Dis 2013;57:e122-e126. doi: 10. $1093 /$ cid/cit291.

[6] Lee GH, Tan BH, Teo EC, Lim SG, Dan YY, Wee A, et al. Chronic infection with camelid hepatitis $E$ virus in a liver transplant recipient who regularly consumes camel meat and milk. Gastroenterology 2016;150:355-357.e3. doi: $10.1053 / j$.gastro.2015.10.048. 
[7] Cossaboom CM, Córdoba L, Dryman BA, Meng XJ. Hepatitis E virus in rabbits, Virginia, USA. Emerg Infect Dis 2011;17:2047-2049. doi: 10.3201/eid1711. 110428.

[8] Huang FF, Haqshenas G, Shivaprasad HL, Guenette DK, Woolcock PR, Larsen $\mathrm{CT}$, et al. Heterogeneity and seroprevalence of a newly identified avian hepatitis e virus from chickens in the United States. J Clin Microbiol 2002;40: 4197-4202.

[9] Wedemeyer H, Pischke S, Manns MP. Pathogenesis and treatment of hepatitis e virus infection. Gastroenterology 2012;142:1388-1397.e1. doi: 10. 1053/j.gastro.2012.02.014.

[10] Hewitt PE, Ijaz S, Brailsford SR, Brett R, Dicks S, Haywood B, et al. Hepatitis E virus in blood components: a prevalence and transmission study in southeast England. Lancet 2014;384:1766-1773. doi: 10.1016/S0140-6736(14) 61034-5.

[11] Terio V, Bottaro M, Pavoni E, Losio MN, Serraino A, Giacometti F, et al. Occurrence of hepatitis $A$ and $E$ and norovirus GI and GII in ready-to-eat vegetables in Italy. Int J Food Microbiol 2017;249:61-65. doi: 10.1016/j. ijfoodmicro.2017.03.008.

[12] Halac U, Béland K, Lapierre P, Patey N, Ward P, Brassard J, et al. Chronic hepatitis $E$ infection in children with liver transplantation. Gut 2012;61: 597-603. doi: 10.1136/gutjnl-2011-300708.

[13] Rein DB, Stevens GA, Theaker J, Wittenborn JS, Wiersma ST. The global burden of hepatitis E virus genotypes 1 and 2 in 2005. Hepatology 2012. 55:988-997. doi: 10.1002/hep.25505.

[14] Bhatia V, Singhal A, Panda SK, Acharya SK. A 20-year single-center experience with acute liver failure during pregnancy: is the prognosis really worse? Hepatology 2008;48:1577-1585. doi: 10.1002/hep.22493.

[15] Pischke S, Hartl J, Pas SD, Lohse AW, Jacobs BC, Van der Eijk AA. Hepatitis E virus: Infection beyond the liver? J Hepatol 2017;66:1082-1095. doi: 10. 1016/j.jhep.2016.11.016.

[16] Balayan MS. Hepatitis E virus infection in Europe: regional situation regarding laboratory diagnosis and epidemiology. Clin Diagn Virol 1993;1:1-9.

[17] Purdy MA, Khudyakov YE. Evolutionary history and population dynamics of hepatitis E virus. PLoS One 2010;5:e14376. doi: 10.1371/journal.pone. 0014376.

[18] Yin X, Li X, Feng Z. Role of envelopment in the HEV life cycle. Viruses 2016;8: 229. doi: 10.3390/v8080229.

[19] Hartl J, Otto B, Madden RG, Webb G, Woolson KL, Kriston L, et al. Hepatitis E seroprevalence in Europe: a meta-analysis. Viruses 2016;8:211. doi: 10. 3390/v8080211.

[20] Adlhoch C, Avellon A, Baylis SA, Ciccaglione AR, Couturier E, de Sousa R, et al. Hepatitis $\mathrm{E}$ virus: Assessment of the epidemiological situation in humans in Europe, 2014/15. J Clin Virol 2016;82:9-16. doi: 10.1016/j.jcv. 2016.06.010.

[21] Boccia D, Guthmann JP, Klovstad H, Hamid N, Tatay M, Ciglenecki I, et al. High mortality associated with an outbreak of hepatitis $\mathrm{E}$ among displaced persons in Darfur, Sudan. Clin Infect Dis 2006;42:1679-1684. doi: 10. $1086 / 504322$

[22] Ahmed JA, Moturi E, Spiegel P, Schilperoord M, Burton W, Kassim NH, et al. Hepatitis E outbreak, Dadaab refugee camp, Kenya, 2012. Emerg Infect Dis 2013;19:1010-1012. doi: 10.3201/eid1906.130275.

[23] Chang Y, Wang L, Geng J, Zhu Y, Fu H, Ren F, et al. Zoonotic risk of hepatitis E virus (HEV): A study of HEV infection in animals and humans in suburbs of Beijing. Hepatol Res 2009;39:1153-1158. doi: 10.1111/j.1872-034X.2009. 00558.x.

[24] Teshale EH, Grytdal SP, Howard C, Barry V, Kamili S, Drobeniuc J, et al. Evidence of person-to-person transmission of hepatitis $\mathrm{E}$ virus during a large outbreak in Northern Uganda. Clin Infect Dis 2010;50:1006-1010. doi: $10.1086 / 651077$.

[25] Huang F, Li Y, Yu W, Jing S, Wang J, Long F, et al. Excretion of infectious hepatitis $E$ virus into milk in cows imposes high risks of zoonosis. Hepatology 2016;64:350-359. doi: 10.1002/hep.28668.

[26] Pischke S, Hiller J, Lütgehetmann M, Polywka S, Rybczynski M, Ayuk F, et al. Blood-borne hepatitis $E$ virus transmission: a relevant risk for immunosuppressed patients. Clin Infect Dis 2016;63:569-570. doi: 10.1093/cid/ciw309.

[27] Hoad VC, Gibbs T, Ravikumara M, Nash M, Levy A, Tracy SL, et al. First confirmed case of transfusion-transmitted hepatitis E in Australia. Med J Aust 2017;206:289-290. doi: 10.5694/mja16.01090.

[28] Boxall E, Herborn A, Kochethu G, Pratt G, Adams D, Ijaz S, et al. Transfusiontransmitted hepatitis $E$ in a 'nonhyperendemic' country. Transfus Med 2006; 16:79-83. doi: 10.1111/j.1365-3148.2006.00652.x.

[29] Haïm-Boukobza S, Ferey MP, Vétillard AL, Jeblaoui A, Pélissier E, Pelletier G, et al. Transfusion-transmitted hepatitis $\mathrm{E}$ in a misleading context of autoimmunity and drug-induced toxicity. J Hepatol 2012;57:1374-1378. doi: 10.1016/j.jhep.2012.08.001

[30] Colson P, Coze C, Gallian P, Henry M, De Micco P, Tamalet C. Transfusionassociated hepatitis E, France. Emerg Infect Dis 2007;13:648-649. doi: 10. 3201/eid1304.061387.

[31] Hauser L, Roque-Afonso AM, Beylouné A, Simonet M, Deau Fischer B, Burin des Roziers $N$, et al. Hepatitis $E$ transmission by transfusion of Intercept blood system-treated plasma. Blood 2014;123:796-797. doi: 10.1182/blood2013-09-524348.

[32] Riveiro-Barciela M, Sauleda S, Quer J, Salvador F, Gregori J, Pirón M, et al. Red blood cell transfusion-transmitted acute hepatitis $E$ in an immunocompetent subject in Europe: a case report. Transfusion 2017;57:244-247. doi: 10.1111/trf.13876.

[33] Kimura Y, Gotoh A, Katagiri S, Hoshi Y, Uchida S, Yamasaki A, et al. Transfusiontransmitted hepatitis $\mathrm{E}$ in a patient with myelodysplastic syndromes. Blood Transfus 2014;12:103-106. doi: 10.2450/2013.0081-13.

[34] Matsui T, Kang JH, Matsubayashi K, Yamazaki H, Nagai K, Sakata H, et al. Rare case of transfusion-transmitted hepatitis $\mathrm{E}$ from the blood of a donor infected with the hepatitis E virus genotype 3 indigenous to Japan: Viral dynamics from onset to recovery. Hepatol Res 2015;45:698-704. doi: 10 . 1111/hepr.12390.

[35] Satake M, Matsubayashi K, Hoshi Y, Taira R, Furui Y, Kokudo N, et al. Unique clinical courses of transfusion-transmitted hepatitis $E$ in patients with immunosuppression. Transfusion 2017;57:280-288. doi: 10.1111/trf.13994.

[36] Matsubayashi K, Kang JH, Sakata H, Takahashi K, Shindo M, Kato M, et al. A case of transfusion-transmitted hepatitis $E$ caused by blood from a donor infected with hepatitis $E$ virus via zoonotic food-borne route. Transfusion 2008;48:1368-1375. doi: 10.1111/j.1537-2995.2008.01722.x.

[37] Kurihara T, Yoshizumi T, Itoh S, Harimoto N, Harada N, Ikegami T, et al. Chronic hepatitis $\mathrm{E}$ virus infection after living donor liver transplantation via blood transfusion: a case report. Surg Case Rep 2016;2:32. doi: 10. 1186/s40792-016-0159-0.

[38] de Vos AS, Janssen MP, Zaaijer HL, Hogema BM. Cost-effectiveness of the screening of blood donations for hepatitis $\mathrm{E}$ virus in the Netherlands. Transfusion 2017;57:258-266. doi: 10.1111/trf.13978.

[39] Aggarwal R, Naik S. Epidemiology of hepatitis E: current status. J Gastroenterol Hepatol 2009;24:1484-1493. doi: 10.1111/j.1440-1746.2009.05933.x.

[40] Dalton HR, Bendall RP, Rashid M, Ellis V, Ali R, Ramnarace R, et al. Host risk factors and autochthonous hepatitis E infection. Eur J Gastroenterol Hepatol 2011;23:1200-1205. doi: 10.1097/MEG.0b013e32834ca4da.

[41] Pischke S, Schulze-Zur-Wiesch J, Lütgehetmann M, Kreuels B, Lueth S, Kapaun $\mathrm{P}$, et al. High clinical manifestation rate in an imported outbreak of hepatitis $E$ genotype 1 infection in a German group of travellers returning from India. Ann Hepatol 2017;16:57-62. doi: 10.5604/16652681.1226815.

[42] Hartl J, Kreuels B, Polywka S, Addo M, Luethgehetmann M, Dandri M, et al. Comparison of autochthonous and imported cases of hepatitis A or hepatitis $\mathrm{E}$. Z Gastroenterol 2015;53:639-643. doi: 10.1055/s-0034-1399236.

[43] Jilani N, Das BC, Husain SA, Baweja UK, Chattopadhya D, Gupta RK, et al. Hepatitis $E$ virus infection and fulminant hepatic failure during pregnancy. J Gastroenterol Hepatol 2007;22:676-682. doi: 10.1111/j.1440-1746. 2007.04913.x.

[44] Bose PD, Das BC, Kumar A, Gondal R, Kumar D, Kar P. High viral load and deregulation of the progesterone receptor signaling pathway: association with hepatitis E-related poor pregnancy outcome. J Hepatol 2011;54: 1107-1113. doi: 10.1016/j.jhep.2010.08.037.

[45] Navaneethan U, Al Mohajer M, Shata MT. Hepatitis E and pregnancy: understanding the pathogenesis. Liver Int $2008 ; 28: 1190-1199$. doi: $10.1111 / \mathrm{j}$ 1478-3231.2008.01840.x.

[46] Smith DB, Ijaz S, Tedder RS, Hogema B, Zaaijer HL, Izopet J, et al. Variability and pathogenicity of hepatitis E virus genotype 3 variants. J Gen Virol 2015; 96:3255-3264. doi: 10.1099/jgv.0.000264.

[47] González Tallón AI, Moreira Vicente V, Mateos Lindemann ML, Achécar Justo LM. Chronic hepatitis E in an immunocompetent patient. Gastroenterol Hepatol 2011;34:398-400. doi: 10.1016/j.gastrohep.2011.02.011.

[48] Höner zu Siederdissen C, Pischke S, Schlue J, Deterding K, Hellms T, SchulerLüttmann $\mathrm{S}$, et al. Chronic hepatitis $\mathrm{E}$ virus infection beyond transplantation or human immunodeficiency virus infection. Hepatology 2014;60:11121113. doi: 10.1002/hep.26987.

[49] Kamar N, Selves J, Mansuy JM, Ouezzani L, Péron JM, Guitard J, et al. Hepatitis $\mathrm{E}$ virus and chronic hepatitis in organ-transplant recipients. $\mathrm{N}$ Engl J Med 2008;358:811-817. doi: 10.1056/NEJMoa0706992.

[50] Gérolami R, Moal V, Colson P. Chronic hepatitis E with cirrhosis in a kidneytransplant recipient. N Engl J Med 2008;358:859-860. doi: 10.1056/ NEJMc0708687.

[51] Haagsma EB, Niesters HG, van den Berg AP, Riezebos-Brilman A, Porte RJ, Vennema $\mathrm{H}$, et al. Prevalence of hepatitis $\mathrm{E}$ virus infection in liver transplant recipients. Liver Transpl 2009;15:1225-1228. doi: 10.1002/lt.21819.

[52] Pischke S, Suneetha PV, Baechlein C, Barg-Hock H, Heim A, Kamar N, et al. Hepatitis $E$ virus infection as a cause of graft hepatitis in liver transplant recipients. Liver Transpl 2010;16:74-82. doi: 10.1002/It.21958.

[53] Koning L, Pas SD, de Man RA, Balk AH, de Knegt RJ, ten Kate FJ, et al. Clinical implications of chronic hepatitis $\mathrm{E}$ virus infection in heart transplant recipients. J Heart Lung Transplant 2013;32:78-85. doi: 10.1016/j.healun.2012. 10.008 .

[54] Pischke S, Stiefel P, Franz B, Bremer B, Suneetha PV, Heim A, et al. Chronic hepatitis e in heart transplant recipients. Am J Transplant 2012;12:31283133. doi: $10.1111 / \mathrm{j} .1600-6143.2012 .04200 . x$. 
[55] Pischke S, Greer M, Hardtke S, Bremer B, Gisa A, Lehmann $P$, et al. Course and treatment of chronic hepatitis $E$ virus infection in lung transplant recipients. Transpl Infect Dis 2014;16:333-339. doi: 10.1111/tid.12183.

[56] Pischke S, Bara C, Behrendt P, Haverich A, Manns MP, Wedemeyer H. Low risk of developing chronic hepatitis $E$ in heart transplant recipients: a prospective 2-year follow-up study. Intervirology 2016;59:254-255. doi: 10.1159/ 000464133.

[57] Kamar N, Lhomme S, Abravanel F, Marion O, Peron JM, Alric L, et al. Treatment of HEV infection in patients with a solid-organ transplant and chronic hepatitis. Viruses 2016;8:222. doi: 10.3390/v8080222.

[58] Mazzola A, Tran Minh M, Charlotte F, Hdiji A, Bernard D, Wendum D, et al. Chronic hepatitis $\mathrm{E}$ viral infection after liver transplantation: a regression of fibrosis after antiviral therapy. Transplantation 2017;101:2083-2087. doi: 10.1097/TP.0000000000001766.

[59] Ingiliz P, Mayr C, Obermeier M, Herbst $H$, Polywka S, Pischke S. Persisting hepatitis $E$ virus infection leading to liver cirrhosis despite recovery of the immune system in an HIV-infected patient. Clin Res Hepatol Gastroenterol 2016;40:e23-e25. doi: 10.1016/j.clinre.2016.01.005.

[60] Naik A, Gupta N, Goel D, Ippagunta SK, Sharma RK, Aggarwal R. Lack of evidence of hepatitis $E$ virus infection among renal transplant recipients in a disease-endemic area. J Viral Hepat 2013;20:e138-e140. doi: 10.1111/ jvh.12027.

[61] Legrand-Abravanel F, Kamar N, Sandres-Saune K, Lhomme S, Mansuy JM, Muscari $F$, et al. Hepatitis $E$ virus infection without reactivation in solid-organ transplant recipients, France. Emerg Infect Dis 2011;17:30-37. doi: 10. 3201/eid1701.100527.

[62] Inagaki $Y$, Oshiro $Y$, Tanaka $T$, Yoshizumi $T$, Okajima $H$, Ishiyama $K$, et al. A nationwide survey of hepatitis $E$ virus infection and chronic hepatitis $E$ in liver transplant recipients in Japan. EBioMedicine 2015;2:1607-1612. doi: 10.1016/j.ebiom.2015.09.030.

[63] Pischke $\mathrm{S}$, Wedemeyer $\mathrm{H}$. Hepatitis $\mathrm{E}$ in transplant recipients: why is this not a problem in Japan? EBioMedicine 2015;2:1564-1565. doi: 10.1016/j. ebiom.2015.11.013.

[64] Te HS, Drobeniuc J, Kamili S, Dong C, Hart J, Sharapov UM. Hepatitis E virus infection in a liver transplant recipient in the United States: a case report. Transplant Proc 2013;45:810-813. doi: 10.1016/j.transproceed.2012.08.020.

[65] Sue PK, Pisanic N, Heaney CD, Mixson-Hayden T, Kamili S, Nelson K, et al. Variability of hepatitis $\mathrm{E}$ serologic assays in a pediatric liver transplant recipient: challenges to diagnosing hepatitis E virus infection in the United States. Transpl Infect Dis 2015;17:284-288. doi: 10.1111/tid.12366.

[66] Chau KH, Dawson GJ, Bile KM, Magnius LO, Sjogren MH, Mushahwar IK. Detection of IgA class antibody to hepatitis $E$ virus in serum samples from patients with hepatitis E virus infection. J Med Virol 1993;40:334-338.

[67] Huang S, Zhang X, Jiang $H$, Yan Q, Ai X, Wang $Y$, et al. Profile of acute infectious markers in sporadic hepatitis E. PLoS One 2010;5:e13560. doi: 10.1371/journal.pone.0013560.

[68] Baylis SA, Blümel J, Mizusawa S, Matsubayashi K, Sakata H, Okada Y, et al. World Health Organization International Standard to harmonize assays for detection of hepatitis E virus RNA. Emerg Infect Dis 2013;19:729-735. doi: 10.3201/eid1905.121845
[69] Gerolami R, Borentain P, Raissouni F, Motte A, Solas C, Colson P. Treatment of severe acute hepatitis E by ribavirin. J Clin Virol 2011;52:60-62. doi: 10. 1016/j.jcv.2011.06.004.

[70] Péron JM, Abravanel F, Guillaume M, Gérolami R, Nana J, Anty R, et al. Treatment of autochthonous acute hepatitis $\mathrm{E}$ with short-term ribavirin: a multicenter retrospective study. Liver Int 2016;36:328-333. doi: 10.1111/liv. 12911.

[71] Péron JM, Dalton H, Izopet J, Kamar N. Acute autochthonous hepatitis E in western patients with underlying chronic liver disease: a role for ribavirin? J Hepatol 2011;54:1323-1324. doi: 10.1016/j.jhep.2011.01.009.

[72] Pischke S, Hardtke S, Bode U, Birkner S, Chatzikyrkou C, Kauffmann W, et al. Ribavirin treatment of acute and chronic hepatitis $\mathrm{E}$ : a single-centre experience. Liver Int 2013;33:722-726. doi: 10.1111/liv.12114.

[73] Shrestha MP, Scott RM, Joshi DM, Mammen MP Jr, Thapa GB, Thapa N, et al. Safety and efficacy of a recombinant hepatitis E vaccine. N Engl J Med 2007; 356:895-903. doi: 10.1056/NEJMoa061847.

[74] Zhu FC, Zhang J, Zhang XF, Zhou C, Wang ZZ, Huang SJ, et al. Efficacy and safety of a recombinant hepatitis $E$ vaccine in healthy adults: a large-scale, randomised, double-blind placebo-controlled, phase 3 trial. Lancet 2010; 376:895-902. doi: 10.1016/S0140-6736(10)61030-6.

[75] Labrique AB, Sikder SS, Krain LJ, West KP Jr, Christian P, Rashid M, et al. Hepatitis $E$, a vaccine-preventable cause of maternal deaths. Emerg Infect Dis 2012;18:1401-1404. doi: 10.3201/eid1809.120241.

[76] WHO. Hepatitis E. vaccine: WHO position paper, May 2015-Recommendations. Vaccine 2016;34:304-305. doi: 10.1016/j.vaccine.2015.07.056.

[77] Wu T, Zhu FC, Huang SJ, Zhang XF, Wang ZZ, Zhang J, et al. Safety of the hepatitis $E$ vaccine for pregnant women: a preliminary analysis. Hepatology 2012;55:2038. doi: 10.1002/hep.25522.

[78] Fearon MA, O'Brien SF, Delage G, Scalia V, Bernier F, Bigham M, et al. Hepatitis $E$ in Canadian blood donors. Transfusion 2017;57:1420-1425. doi: 10. $1111 /$ trf. 14089

[79] Gallian P, Lhomme S, Piquet $Y$, Sauné K, Abravanel F, Assal A, et al. Hepatitis E virus infections in blood donors, France. Emerg Infect Dis 2014;20:19141917. doi: 10.3201/eid2011.140516.

[80] Vollmer T, Diekmann J, Johne R, Eberhardt M, Knabbe C, Dreier J. Novel approach for detection of hepatitis $E$ virus infection in German blood donors. J Clin Microbiol 2012;50:2708-2713. doi: 10.1128/JCM.01119-12.

[81] Baylis SA, Gärtner T, Nick S, Ovemyr J, Blümel J. Occurrence of hepatitis E virus RNA in plasma donations from Sweden, Germany and the United States. Vox Sang 2012;103:89-90. doi: 10.1111/j.1423-0410.2011.01583.x.

[82] Sauleda S, Ong E, Bes M, Janssen A, Cory R, Babizki M, et al. Seroprevalence of hepatitis E virus (HEV) and detection of HEV RNA with a transcriptionmediated amplification assay in blood donors from Catalonia (Spain). Transfusion 2015;55:972-979. doi: 10.1111/trf.12929.

[83] Hogema BM, Molier M, Sjerps M, de Waal M, van Swieten P, van de Laar T, et al. Incidence and duration of hepatitis $E$ virus infection in Dutch blood donors. Transfusion 2016;56:722-728. doi: 10.1111/trf.13402.

[84] Stramer SL. Current perspectives in transfusion-transmitted infectious diseases: emerging and re-emerging infections. ISBT Sci Ser 2014;9:30-36. doi: 10.1111 /voxs.12070. 